\title{
Soil Water Studies in Oxisols and Ultisols of Puerto Rico: II. Moisture Retention and Availability ${ }^{1}$
}

\author{
James M. Wolf and Matthew Drosdoff ${ }^{2}$
}

\begin{abstract}
The two Oxisols studied, one very sandy (Bayamón) and the other high in clay (Catalina), tended to dewater at low tensions, whereas soil water release in the Ultisols extended over a wider range of tensions. The sandy soil failed to release appreciable water above 1 bar of tension.

Field capacity was established at 1/15 bar for the sandy soil and 1/20 bar for the clayey soils. The available water stored in the top $30 \mathrm{~cm}$ of the soil profile was determined to be $3.6,5.0,5.5$, and $6.0 \mathrm{~cm}$ for Bayamón, Humatas, Torres, and Catalina, respectively. For Bayamón and Catalina, the two Oxisols, the bulk of the water was released between field capacity and 1 bar. In contrast to the Oxisols, a high proportion of the water in the Ultisols, Humatas and Torres, was available only at tensions above 1. bar. The Catalina soil was by far the best in terms of water supplying characteristics, while Humatas and Bayamón were the worst.
\end{abstract}

\section{INTRODUCTION}

In a previous paper (4), studies on water movement in some Oxisols and Ultisols of Puerto Rico were reported. This paper reports data on water holding capacity, available water, and influence of soil water tension on the water content of those same soils.

\section{MATERIALS AND METHODS}

The soils included in the study were Humatas (Typic Tropohumults), Catalina (Typic Haplorthox), Torres (Orthoxic Palehumults), and

${ }^{1}$ Submitted to Editorial Board April 25, 1974.

${ }^{2}$ Formerly lecturer, Department of Agricultural Engineering, now with CIDIAT, Mérida, Venezuela, and Professor of Soil Science, Department of Agronomy, respectively, Cornell University, Ithaca, N.Y. in cooperation with the Agricultural Experiment Station of the University of Puerto Rico and with the support of the U.S. Agency for International Development under Research Contract csd 2490. The authors are indebted to several people for assistance during the course of the work. Dr. Richard Fox was singularly helpful in providing logistic support. Gaston Amedee assisted greatly in both the lab and field. Drs. Levine and Bouldin from Comell University, willingly gave their time in reviewing this material. Many other people at Río Piedras, Corozal, and the other sites gave assistance when needed. Special thanks are due Dr. Miguel A. Lugo-López for his assistance in preparing the manuscript for publication. Lastly, the senior author acknowledges the continued support by the Agricultural Engineering Department, Cornell University, which enabled him to undertake this work. 
Bayamón (Psammentic Haplorthox). The first three were clayey, while the last was a loamy sand.

Details on the sampling, laboratory determinations, and field instrumentation are given by Wolf and Drosdoff in paper I of this series (4). Water content versus tension determinations in the range 0 to $3 / 4$ bar were run on undisturbed core samples; disturbed samples were used in the range 1 to 15 bars. Each point on a curve is generally an average of four laboratory determinations. As two distinct methods have been used for determining soil water tension $\times$ water content relations, some overlap may exist in the relationships in the vicinity of 1 bar. Therefore,

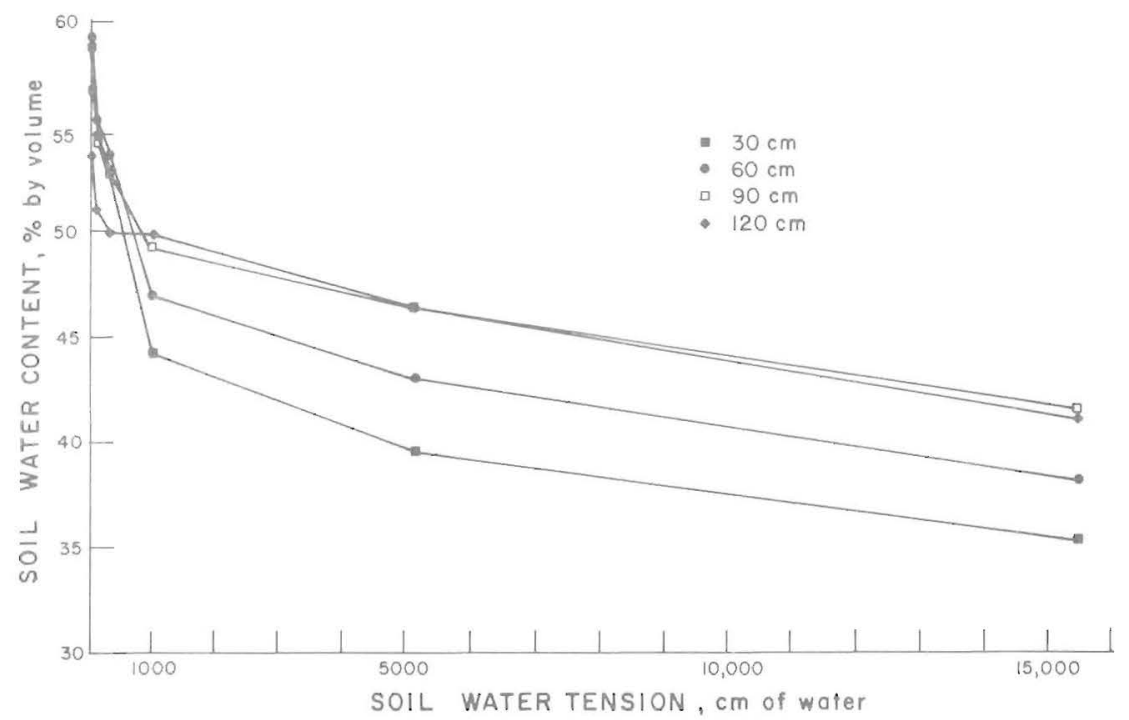

FIG. 1.-Soil water content versus tension for 0 to 15 bars in Humatas soil at four depths.

water contents for certain of these tensions were obtained by interpolation.

\section{RESULTS AND DISCUSSION}

SOIL WATER CONTENT VERSUS SOIL WATER TENSION

Soil water characteristic curves (or soil water release curves) relate volumetric soil water content to soil water tension. They are useful in describing the percentage of water retained for a particular horizon of a soil. Since curves characterize a soil type and depth, they may be used to determine soil water content once soil water tensions have been established using tensiometers. Use of tensiometers and these curves permits calculation of water content changes in the soil profile.

Figures 1 to 4 are soil water characteristic curves for the four soils. On 
each graph four soil water release curves have been drawn corresponding to $30-, 60-, 90-$, and $120-\mathrm{cm}$ depths.

A comparison of the soil water release curves reveals that there are differences in shapes of the curves. At low tensions ( 0 to $100 \mathrm{~cm}$ of water) the curves for the Bayamón soil, a sandy Oxisol, are very steep. In this soil the bulk of the pores dewater at very low tensions. The curves are also fairly steep for the Catalina soil, a clayey Oxisol, but are less steep for Torres, a clayey Ultisol intergrade to Oxisol. In contrast, the curves for the Humatas soil, a clayey Ultisol, are even less steeply sloping, indicative of gradual water release in this tension range.

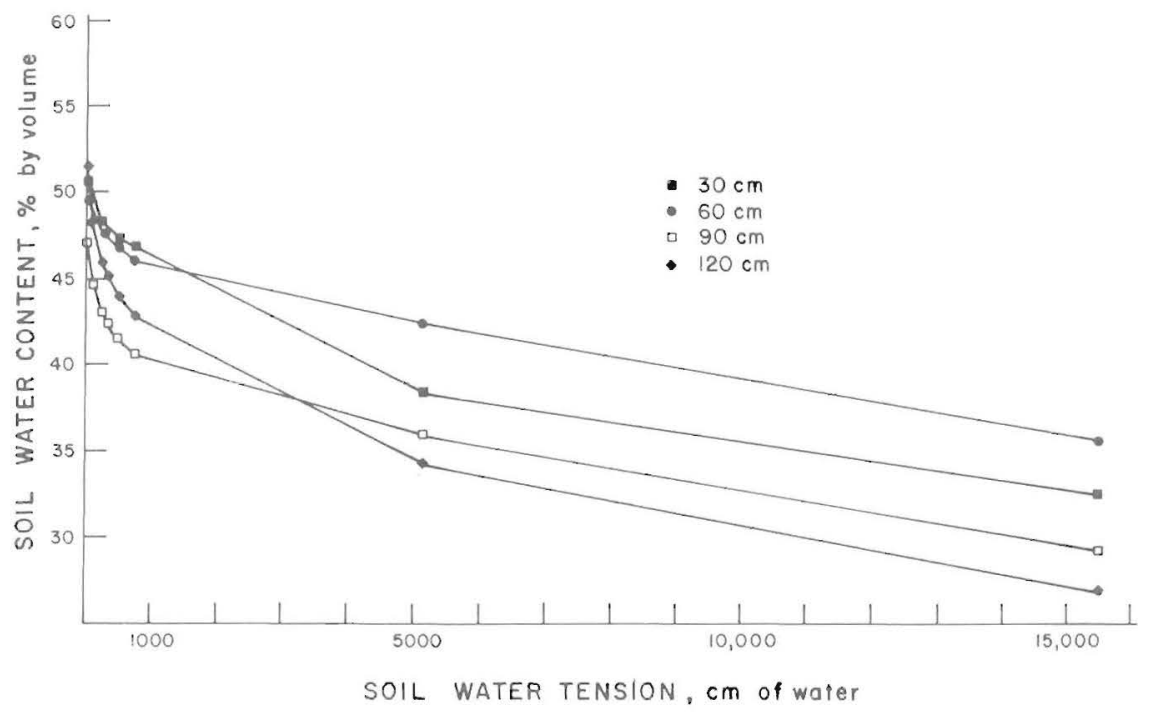

FIG, 2.- Soil water content versus tension for 0 to 15 bars in Catalina soil at four depths.

Variation between depths was greatest for the Humatas clay, the soil with the most pronounced horizonation. For example, the $30-$ and $60-\mathrm{cm}$ depths contained as much as $5 \%$ or more water than the $90-$ and $120-\mathrm{cm}$ depths at a given tension.

Figure 4 illustrates that the sandy Bayamón soil practically ceased to release water above 1 bar of tension. In contrast to the Bayamón, the relative steepness of the curves for the Humatas soil (fig. 1) indicates that this soil can continue to release appreciable amounts of water stored in the profile at tensions above 1 bar. In fact, approximately threefourths of the available water in this soil would be stored at tensions above 1 bar. The Catalina and Torres soils behaved in an intermediate manner, with the former soil tending to release water in a manner most 
similar to Bayamón (both are Oxisols), and with the Torres soil tending somewhat toward the Humatas (both are Ultisols).

WATER HOLDING CAPACITY AND AVAILABLE WATER

The amount of available water for crop growth is considered to be the amount held in the range from field capacity to permanent wilting point (15-bar percentage). Field capacity has been defined as the water content of the soil after the soil has been saturated and allowed to drain freely for 2 or 3 days in the absence of evaporation. In the laboratory this determination usually has been correlated with a tension of $1_{3}$ bar. Some

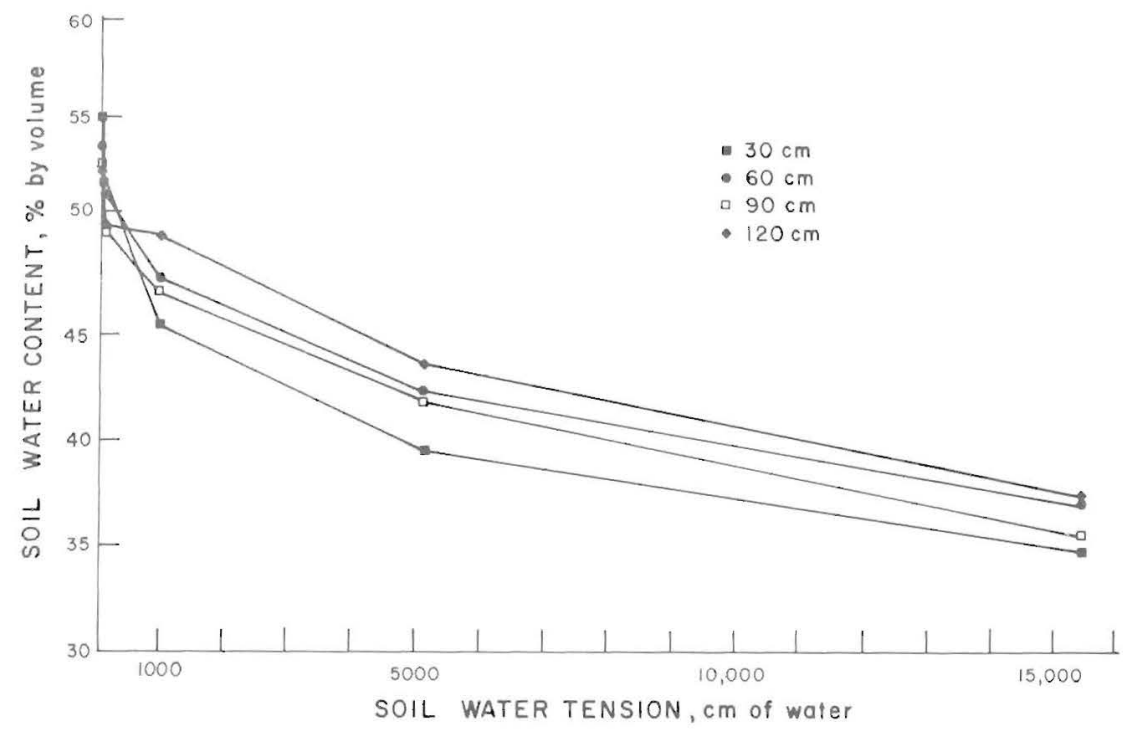

FiG, 3.- Soil water content versus tension for 0 to 15 bars in Torres soil at four depths.

workers (3) have associated 3 -bar percentage with field capacity. Griffin et al. (2) have taken the available water range to be that held between ${ }^{1}$ s and 15 bars. For the Puerto Rico soils reported herein, 1:3-bar percentage gives a poor estimate of field capacity.

It is apparent from figures 3 and 4 of paper I of this series that the tension associated with drainage after 3 days is depth dependent. Also, it was observed that tensions in the field under conditions of free drainage (but no evaporation) do not reach $1 / 3$ bar in 3 days but instead drain to 20 to $80 \mathrm{~cm}$ of water (roughly $1 / 50$ to $1 / 12$ bar). Therefore, field capacity was considered to be $1 / 15$ bar for the sandy Bayamón and 1/20 bar for the clayey soils.

The lower end of the available water range has generally been 
established at the wilting point or 15-bar percentage. This implies two things: 1) that the entire amount of water is available to plants, and 2) that it is uniformly available. Regarding point 1 , it is very unlikely that plants can use water from this entire range. Water uptake by plants is a function of root density and water conduction by the soil. At high tensions, water conduction will be slow and although ample water may be present in the soil, the supply system may not keep pace with plant needs if evaporative demand is high. Under those circumstances it would be correct to say that the soil water is not available, at least in the dynamic sense. Point 2 has generally been refuted for most crops. Plants

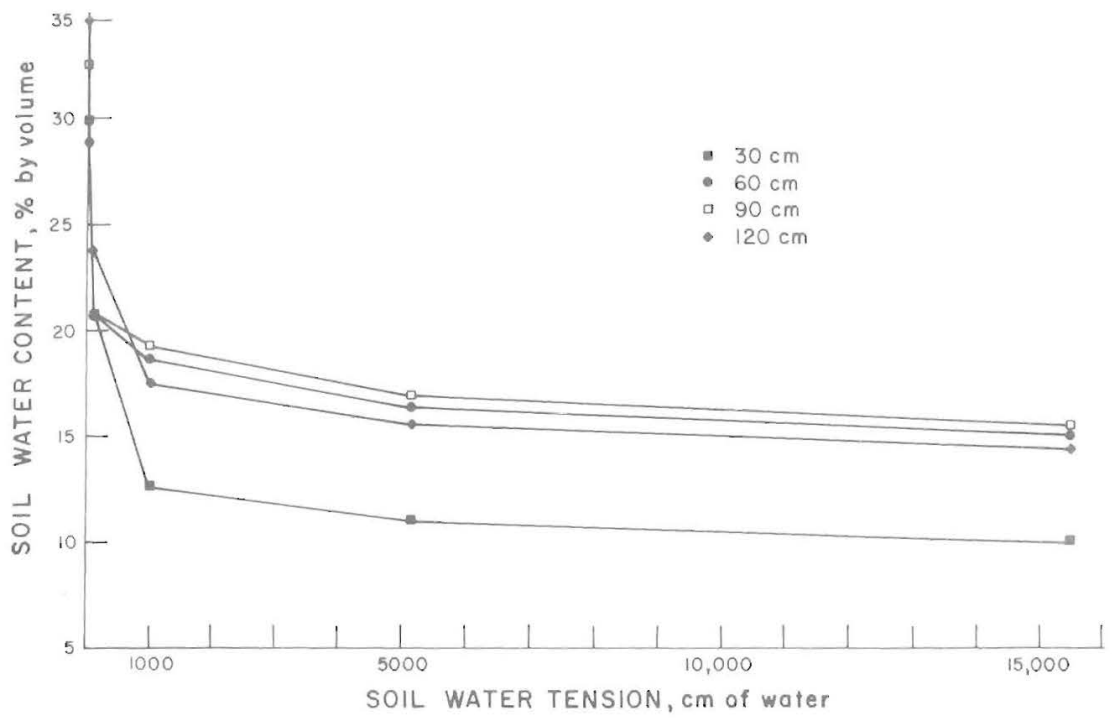

FIG. 4.- Soil water content versus tension for 0 to 15 bars in Bayamon soil at four depths.

will show stress and yields will be reduced at soil tension levels considerably below 15 atmospheres. In conclusion, one might say that for the soils studied the entire range of available water has been shifted toward the lower end of the tension range, 1/20 to perhaps 1 bar. Gardner (1) expressed similar conclusions.

The question naturally arises as to the magnitude of the additional water available in the soil from $1 / 15$ or $1 / 20$ bar to 15 bars versus that which would be calculated conventionally by considering the available range to be $1 / 3$ to 15 bars. The magnitude of that increase was determined to be on the order of 10 to $15 \%$ more water in the clayey soils, and approximately $33 \%$ more water in the sandy soil. It is apparent that correct establish- 
ment of the upper range of available water is extremely critical on a sandy soil where water contents change drastically with small soil water tension changes. As root penetration may be restricted to the upper 30 $\mathrm{cm}$ because of subsoil acidity or other factors, even a $15 \%$ increase in water storage may be important.

Figure 5 has been drawn to compare the available water holding capacities for 30 - and 60 -cm rooting depths for the four soils studied. Data for figure 5 were taken from table 1.

For the Bayamón soil (sandy Oxisol) the bulk of the water is held at tensions between $1 / 15$ and 1 bar. As much or more water was lost between

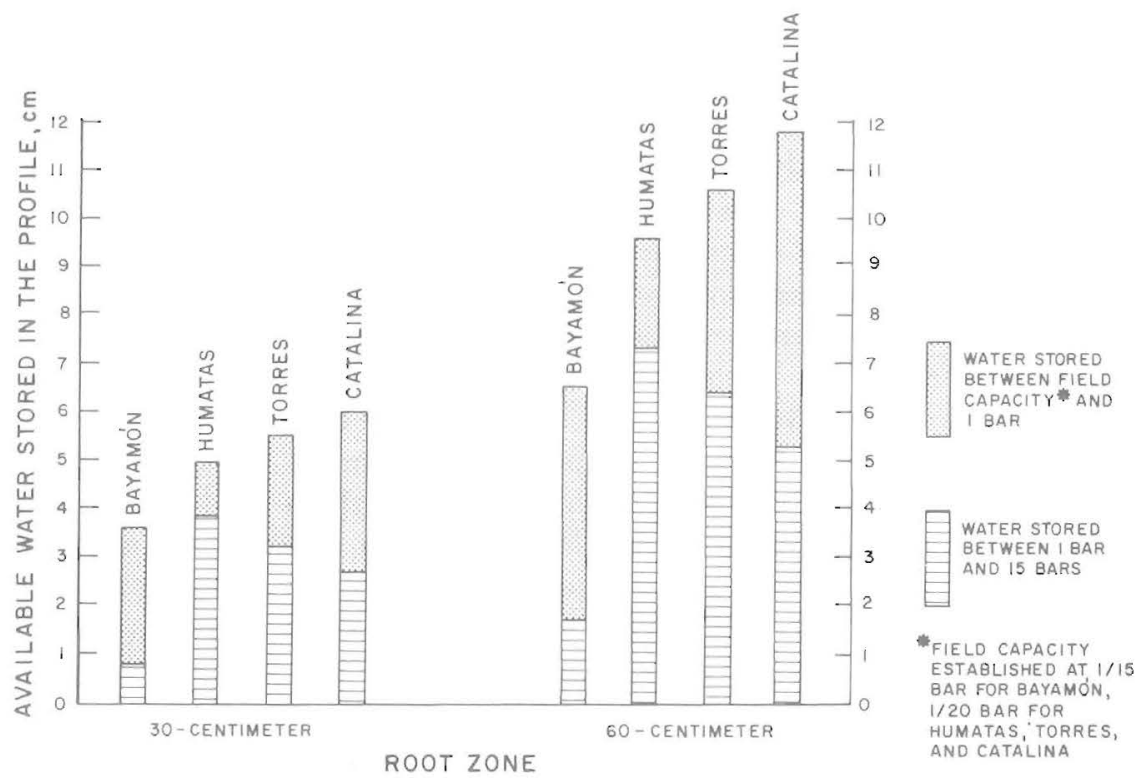

FIG. 5.-Water holding capacity of four Puerto Rico soils.

saturation and $1 / 15$ bar as between $1 / 15$ and 1 bar. This soil has a low available water holding capacity. When soil water tensions reach 1 bar, the crop would have available at most a 1-day supply of water for transpiration, assuming a $30-\mathrm{cm}$ root zone. Due to capillary conductivity considerations, it is unlikely that this water would be available for crop growth.

In contrast to the Bayamón, the bulk of the water in the Humatas soil would be available only at tensions above 1 bar. This may be adequate if crop root density and soil capillary conductivity were high and evaporative demand low. However, under conditions of poor root distribution, low capillary conductivity, and high evaporative demand, the water may 
TABLE 1.-A mount of available water (in centimeters) stored in the soil profile at various tentions for four Puerto Rico soils

\begin{tabular}{|c|c|c|c|c|}
\hline \multirow{2}{*}{ Tension } & \multicolumn{4}{|c|}{ Available water stored in indicated depth profile } \\
\hline & Bayamón & Torres & Humatas & Catalina \\
\hline \multicolumn{5}{|c|}{ 30-cm profile } \\
\hline Field capacity ${ }^{1}$ & 3.6 & 5.5 & 5.0 & 6.0 \\
\hline 1 bar & .8 & 3.1 & 4.1 & 2.7 \\
\hline 15 bars & 0 & 0 & 0 & 0 \\
\hline \multicolumn{5}{|c|}{ 60-cm profile } \\
\hline Field capacity & 6.5 & 10.6 & 9.6 & 11.7 \\
\hline 1 bar & 1.4 & 6.4 & 7.1 & 5.3 \\
\hline 15 bars & 0 & 0 & 0 & 0 \\
\hline
\end{tabular}

${ }^{2}$ Field capacity established to be $1 / 15$ bar for Bayamón soil and $1 / 20$ bar for Torres, Humatas, and Catalina soils.

be inadequate to supply plant requirements. Under the latter conditions, the soil is likely to be considered "droughty." Thus, while actual water storage would be greater than in Bayamón, the Humatas soil may also be a poor one from a standpoint of water supplying characteristics under certain crop and climatic conditions.

Like Humatas, the Torres soil contained a high proportion of water stored above 1 bar. This is mitigated by the fact that Torres contained $50 \%$ more water (2 days of evapotranspiration in a $30-\mathrm{cm}$ profile assuming an ET of $0.5 \mathrm{~cm} /$ day), than Humatas in the range $1 / 20$ to 1 bar.

The Catalina soil would have a large reservoir of available water. A large proportion of it would be available at low tensions making this soil relatively good in water supplying characteristics. The data in table 2 show that the 90 - and $120-\mathrm{cm}$ depths in this soil had a much narrower range of available water.

The two Oxisols, one sandy (Bayamón) and the other clayey (Catalina), held a greater proportion of water stored between $1 / 15$ bar and 1 bar. In contrast, the Ultisols (Humatas and Torres) had a greater proportion stored between 1 bar and 15 bars. This is probably due to soil structure characteristics in the Ultisols which released water relatively slowly. The uniformity of the Oxisol profile, combined with strong aggregate stability and a large number of macropores, would favor rapid water release and availability. It would be premature, however, to apply these conclusions to all Oxisols and Ultisols.

\section{RESUMEN}

Los dos Oxisols, estudiados, uno muy arenoso (Bayamón) y el otro con un alto contenido de arcilla (Catalina), liberaron agua a tensiones bajas, mientras que en el caso de los Ulti- 
TABLE 2.-Accumulated centimeters of water released as soil is dewatered from zero tension (saturation) to tension indicated

\begin{tabular}{|c|c|c|c|c|c|}
\hline Depth & Tension & Humatas & Catalina & Torres & Bayamon \\
\hline \multicolumn{6}{|l|}{$\mathrm{Cm}$} \\
\hline \multirow[t]{7}{*}{30} & $0 \mathrm{~cm}$ & - & - & - & - \\
\hline & 50 & 0.45 & 1.05 & 0.69 & $2.40^{1}$ \\
\hline & 100 & .60 & 1.32 & .96 & 2.82 \\
\hline & 333 & .87 & 1.89 & 1.38 & 3.75 \\
\hline & 1 bars & 1.35 & 4.38 & 2.97 & 5.22 \\
\hline & 5 & 3.69 & 5.79 & 4.74 & 5.70 \\
\hline & 15 & 5.43 & 7.05 & 6.18 & 6.00 \\
\hline \multirow[t]{7}{*}{60} & $0 \mathrm{~cm}$ & - & - & - & - \\
\hline & 50 & .18 & .93 & .42 & $1.92^{1}$ \\
\hline & 100 & .39 & 1.20 & .69 & 2.40 \\
\hline & 333 & .84 & 1.68 & 1.17 & 3.15 \\
\hline & 1 bars & 1.44 & 3.69 & 1.86 & 3.54 \\
\hline & 5 & 2.37 & 4.89 & 3.48 & 3.78 \\
\hline & 15 & 4.38 & 6.33 & 5.10 & 4.17 \\
\hline \multirow[t]{7}{*}{90} & $0 \mathrm{~cm}$ & - & - & - & - \\
\hline & 50 & .42 & .60 & .60 & $3.00^{1}$ \\
\hline & 100 & .72 & .81 & .87 & 3.57 \\
\hline & 333 & 1.38 & 1.14 & 1.47 & 4.53 \\
\hline & 1 bars & 2.04 & 2.25 & 1.80 & 4.86 \\
\hline & 5 & 3.30 & 3.12 & 3.33 & 4.98 \\
\hline & 15 & 5.28 & 4.56 & 5.25 & 5.13 \\
\hline \multirow[t]{7}{*}{120} & $0 \mathrm{~cm}$ & - & - & - & - \\
\hline & 50 & .54 & .57 & .39 & $2.73^{1}$ \\
\hline & 100 & .99 & .78 & .66 & 3.27 \\
\hline & 333 & 1.92 & 1.11 & 1.32 & 4.26 \\
\hline & 1 bars & 2.70 & 1.53 & 1.86 & 5.16 \\
\hline & 5 & 5.16 & 2.19 & 2.61 & 5.73 \\
\hline & 15 & 7.35 & 3.75 & 4.50 & 6.09 \\
\hline
\end{tabular}

${ }^{1} 70 \mathrm{~cm}$ of tension.

sols, la liberación de agua occurió en una amplitud mayor de tensiones. El suelo arenoso no liberó agua en cantidades apreciables a una tensión mayor de 1 bar.

Se estableció que la capacidad de campo en el suelo arenoso ocurre a 1/, bar mientras que en los arcillosos ocurre a $1 / 20$ bar. Se determinó que el agua disponible (en centímetros) acumulada en los $30 \mathrm{~cm}$. superficiales del perfil del suelo era de $3.6,5.0,5.5$ y 6.0 para los suelos Bayamón, Humatas, Torres y Catalina, respectivamente. En el caso de Bayamón y Catalina, los dos Oxisols, la mayor parte del agua se liberó en tensiones entre la capacidad de campo y 1 bar. En contraste con los Oxisols, una alta proporción del agua en los Ultisols, Humatas y Torres, estuvo disponible solo a tensiones mayores de 1 bar. El suelo Catalina es el mejor de todos a base de sus características de suministro de agua, mientras que el Humatas y el Bayamón pueden considerarse como los peores. 


\section{LITERATURE CITED}

1. Gardner, W. R., Laboratory measurement of available water, Soil. Sci. Soc. Amer. Proc. 35: 852, 1971.

2. Griffin, R. H., II, Ott, B. J., and Stone, J. F., Effect of water management and surface applied barriers on yield and moisture utilization of grain sorghum in the Southern Great Plains, Agron. J. 58: 449-52, 1966.

3. Richards, L. A., and Weaver, L. R., Moisture retention by some irrigated soils as related to moisture tension, J. Agr. Res. 69: 215-35, 1944.

4. Wolf, J. M., and Drosdoff, M., Soil water studies on Oxisols and Ultisols of Puerto Rico: I. Water movement, J. Agr. Univ. P. R. 60(3): 375-85, 1976. 